\title{
Minimally invasive liver surgery: the Charité experience
}

\author{
Maximilian Nösser(D), Linda Feldbrügge(D), Johann Pratschke(D) \\ Department of Surgery, Charité - Universitätsmedizin Berlin, Campus Charité Mitte and Campus Virchow-Klinikum, Berlin, Germany
}

\begin{abstract}
Minimally invasive liver surgery (MILS) was established as last abdominal surgical specialty through the 1990s. With a shift from mainly benign to malignant indications, MILS was shown to be equal to open liver surgery in terms of oncological outcomes, with benefits in intraoperative blood loss, postoperative pain, postoperative complication rates, hospital length of stay and quality of life. With colorectal liver metastases and hepatocellular carcinoma as the most common indications, most liver resection can be performed minimally invasive nowadays, including patients with liver cirrhosis. Initially perceived limitations of laparoscopic liver surgery were weakened by gaining experience, technical progress and pioneering of new resection approaches. Lately robotic liver surgery was adopted to the field of MILS to further push the limits. To simplify first resections, technical variations of the minimally invasive approach can be utilized, and difficulty scores help to select resections suitable to the level of experience. We hereby give an overview of the establishing of a minimally invasive liver surgery program at our center.
\end{abstract}

Keywords: Minimally invasive liver surgery, laparoscopic liver surgery, robotic liver surgery, laparoscopy, liver, robotics

Cite this article as: Nösser $M$, Feldbrügge $L$, Pratschke J. Minimally invasive liver surgery: the Charité experience. Turk J Surg 2021; 37 (3): 199-206.

Corresponding Author Maximilian Noesser

E-mail: maximilian.noesser@charite.de

Received: 03.07.2021

Accepted: 12.08.2021

Available Online Date: 28.09 .2021

O Copyright 2021 by Turkish Surgical Society Available online at www.turkjsurg.com

DOI: 10.47717/turkjsurg.2021.1011

\section{INTRODUCTION}

\section{Development of minimally invasive liver surgery}

In the early 1950s, Caroli was one of the first to consider a role for laparoscopy in liver pathologies (1). Decades later, in the 1990s, different surgeons and centers around the world transferred their expertise from open liver surgery to minimally invasive liver surgery (MILS), and could show in a number of retrospective publications that it was equivalent to open surgery, and could even decrease perioperative blood loss, short term morbidity and mortality (2-4). In recent years, a few prospective, randomized controlled trials (RCT) have been added to the pile of evidence, confirming advantages of MILS over open surgery $(5,6)$.

\section{Adoption of MILS in different liver malignancies}

In the beginning MILS was mainly performed for non-malignant liver lesions, due to initial concerns regarding oncological outcomes in comparison to open liver surgery $(7,8)$. By now, the two most common indications for MILS are colorectal liver metastases (CRLM) and hepatocellular carcinomas (HCC), reflecting our experience $(9,10)$. Based on a large number of retrospective studies on MILS for CRLM, two meta-analyses have shown MILS to be favorable to open liver resections for having significantly lower morbidity, reduced intraoperative blood loss and transfusion as well as a decreased length of stay in the hospital, but longer operation times $(11,12)$. No differences were observed in disease recurrence or survival rates. The first RCT comparing open and laparoscopic liver resections for CRLM by Fretland et al. (OSLO-COMET) could demonstrate a significantly reduced rate of postoperative complications as well as a shorter length of stay (5). Rates of R0 resections were equal to open surgery. Contrary to prior findings operation times were similar in MILS and open surgery, possibly reflecting the overall learning curve.

Similarly to CRLM, MILS has been increasingly used for patients with HCC, who usually have underlying liver cirrhosis. Both retrospective studies and a small RCT have demonstrated advantages of laparoscopic techniques over open surgery, such as fewer postoperative complications, especially liver failure (13). Intrahepatic cholangiocarcinomas (iCC) were slower to be elected for MILS, due to initial concerns 
about the radicality of hilar lymphadenectomy in the laparoscopic approach, which we presented to be feasible in one of the largest report on MILS for iCC (14).

\section{Standardization and future challenges}

By 2021, MILS has become the standard in the field of liver surgery in many centers including ours. Conventional open liver surgery has not been replaced completely, as it is currently still used in cases of large tumors and complex vascular and biliary reconstructions. However, we and others have gained vast experience in MILS, and continue to extend boundaries and indications, along with the constant development of further technical advances, such as robotic surgery. At this point, it is becoming ever more important to move from experimental, individual approaches at different centers around the world to a standardization in surgical techniques and training.

After the first guideline meetings beginning with the pioneering conference in Louisville, USA in 2008, leading laparoscopic liver surgeons founded the International Laparoscopic Liver Society (ILLS) in 2016, with the superior intention to introduce international technical as well as reporting standards $(15,16)$.

To meaningfully compare results from different studies, especially those of retrospective design and including eras of learning curves, a classification of surgical difficulty is needed. In the first international guideline conference in Louisville, USA in 2008, the extent of the hepatic resection was divided into three categories of complexity, defining posterolateral segments $(4 a, 7,8)$ to be the most difficult along with hemihepatectomies as well as trisectionectomies (category III), while resections of anterolateral segments $(4 b, 5,6)$ as well as left lateral sectionectomy $(2,3)$ were classified to be less complex in the laparoscopic approach (category II), biopsies and small wedge resections (category I) were rated as the least difficult ones (15). Consecutively the Difficulty Scoring System was introduced and later extended by the Iwate criteria to calculate the complexity of the resection by preoperative parameters $(17,18)$. The Iwate criteria include the high scoring aspects of segment of tumor location and extent of resection as well as tumor size, preoperative liver function defined by Child-Pugh-Score (A and B), proximity to major vessels as well as the laparoscopic approach. The main intention of the Iwate criteria was matching the skill level of the surgeon with the complexity of the planned resection to structure the training of laparoscopic liver surgeons and therefore improve safety for the patients.

Not even two decades after LLS was first established, robotic liver surgery became a part of the MILS spectrum with first scientific reports in 2008 with the intention to further improve surgical accuracy, enable more complex resections and also to reduce fatigue of the surgeon $(19,20)$. Robotic liver surgery has not been implemented outside of few specialized centers around the world. Currently, several promising studies about the safety, feasibility and potential advantages are being published.

\section{Establishment of a laparoscopic liver surgery program}

At the Department for Surgery of the Charité - Universitätsmedizin Berlin, the first laparoscopic liver resection was a wedge resection of a single CRLM in segment 6, performed in 2008. In the following five years, another 20 minor resections were performed in a highly selected group of patients. From 2015 on, we focused efforts to form a structured program for MILS to further increase the quality and the number of cases per year.10 The number of laparoscopic liver resections rose from 16 (2014) to 95 (2017), while the share of major resections ( $\geq 3$ segments) increased from $14.3 \%$ to $48.4 \%$ in the same time. Despite the escalating surgical difficulty, the rate of severe complications (Clavien-Dindo $\geq 11$ la) remained similar. Robotic liver surgery was added in 2018, framed in a prospective, post-marketing observational study in collaboration with Intuitive (Intuitive Surgical Inc., Sunnycale, CA, USA), in order to assess the quality and the value of the new technique in standardized, scientific way during implementation. An overview of the numbers of laparoscopic and robotic liver resections at our center since 2014 is displayed in Figure 1. In the following sections, we address some technical challenges, and discuss the strategies we adopted in the years of implementing MILS.

\section{Aspects of Technical Difficulty In Minimally Invasive Liver Surgery \\ Tumor location}

The "classic laparoscopic segments" were originally defined as anterolateral segments 2, 3, 4b, 5, 6 (15). They seemed to be accessible through the laparoscopic approach from very early on, especially as the surgical strategy of laparoscopic liver resections shifted from the 'anterior' or 'ventral' approach in open surgery to a 'caudal approach' in MILS, which exposes the hilar plate and the vena cava as leading structures in the best possible way during primarily anatomical resection (18). With a growing experience in MILS, posterosuperior segments were increasingly also resected minimally invasively, which are regarded more difficult to access in the Iwate criteria. The 'caudal approach' was later augmented by the 'diamond technique', when posterosuperior segments were addressed through parenchyma-sparing resections (21). By now MILS of posterosuperior segments is the approach of choice independent from the indication at our center (22).

\section{Extent of resection}

In the early stages of MILS, predominantly minor resections were performed, starting with left lateral sectionectomies in the 1990s as well as simple anatomical segmentectomies $(2,23)$. With the intention of foremost oncological radicality with clear margins, consequently resection of 3 or more segments - defined as major resections - were performed, with the principle of keeping 


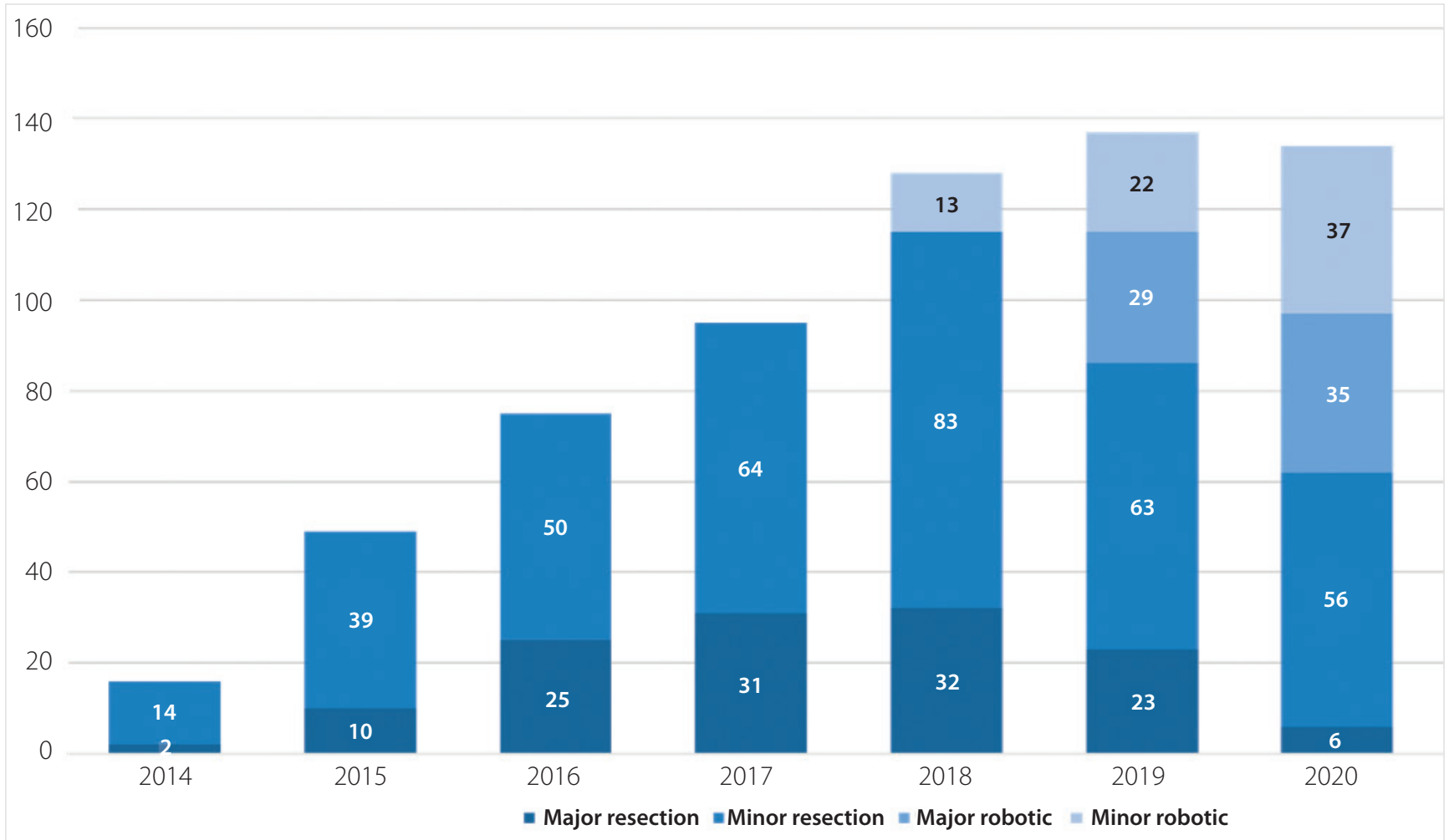

Figure 1. Development of minimally invasive liver surgery at the Charité, Department for Surgery between 2014 -2020.

the volume of the remnant liver as big as possible. Within the last five years, the percentage of major resections performed minimally invasively at our center nearly doubled (Figure 1), so that MILS also became the standard procedure for left (segments 2-4) or right (segments 5-8) anatomical hepatectomies (also hemihepatectomy) at our center as well as most specialized centers across the world, with even economic advantages $(24,25)$. If indicated e.g. for iCC, even extended left or right hepatectomy can be performed minimally invasive today (14).

\section{Tumor size}

Tumor lesions sized below $3 \mathrm{~cm}$ commonly do not affect the difficulty of the planned resection, as indicated by the Iwate criteria (18). MILS for large lesions $(5-10 \mathrm{~cm}$ ) and also giant lesions $(>10 \mathrm{~cm})$ was shown to be possible in retrospective analysis, although giant tumors had greater blood loss and prolonged operative times compared to large lesions, but the evidence is overall limited (26). Tumor perforation through shear forces, lesions size-related deviation from regular trocar placement and specimen recovery has to be taken under consideration along with the surgeon's own experiences prior to choosing MILS for large hepatic lesions.

\section{Technical variations}

Previously standardized laparoscopic techniques (multi-incision, hand-assisted and hybrid-laparoscopy) were adopted by lapa- roscopic liver surgeons, with individual preferences in different countries (15). In terms of difficulty, the Iwate criteria postulated a reduced complexity when hand-assisted or hybrid approaches were chosen rather than a pure laparoscopic approach (18). Within our laparoscopic liver surgery program, we investigated the different approaches from very early on. At our center we applied hand-assisted procedures ( $n=187,65.2 \%)$ significantly more than multi-incision laparoscopic approaches ( $\mathrm{n}=$ 100, 34.8\%) between 2013 and 2018, with a decreasing use of hand-assisted surgery over time. For malignant lesions as well as for major resections hand-assisted laparoscopy was used significantly more in those earlier years. We found no differences in operative time and major postoperative complications (27). In our experience the application of hand-assisted laparoscopic liver resections is valuable especially in the establishing phase of a laparoscopic liver surgery program, but can be decreased once the necessary experience in pure laparoscopic resections is achieved. We therefore left the hand-assisted approach in the last few years (10).

\section{Liver cirrhosis}

One of the main aspects of liver surgery for HCC in general is the mostly underlying liver cirrhosis, which can lead to severe postoperative complications, including hepatic insufficiency with formation of ascites and also liver failure, resulting in a contraindication of liver resections for patients with HCC and Child- 


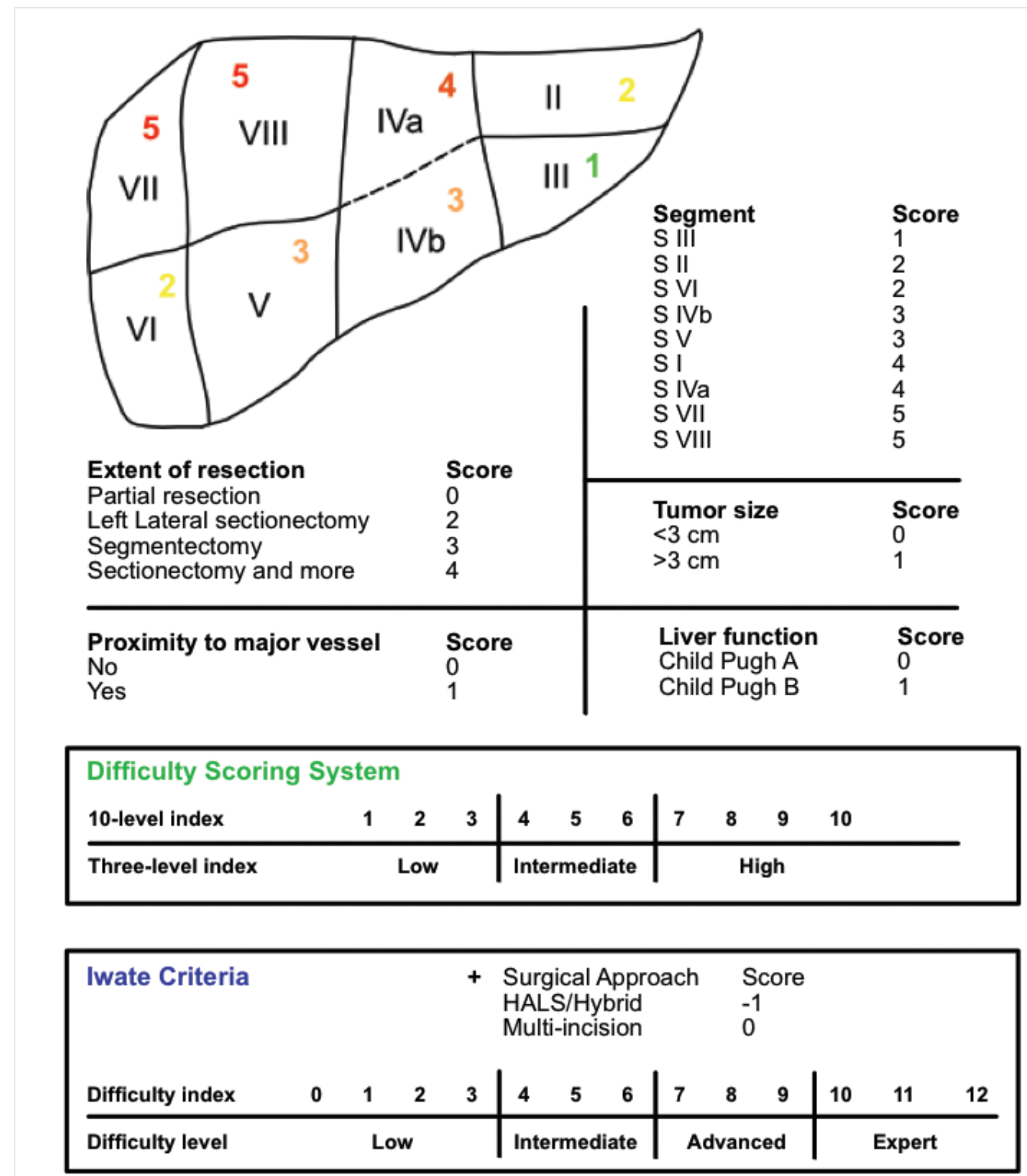

Figure 2. MILS difficulty scores: Difficulty scoring system (DSS) with five categories. Iwate criteria with the same categories as the DSS adding the type of laparoscopic approach $(17,18)$.

Pugh C cirrhosis, as well as for lower grade cirrhosis under circumstances likes multinodular lesions and portal vein invasion (28). Between 2010 and 2015, we performed 21 laparoscopic liver resections for HCC lesions in Child-Pugh A cirrhosis (29). For all patients preoperatively an assessment of the functional reserve of the liver was performed by using a 13C-labelled methacetin breath test (LiMAx) which was developed at our center (30). All patients had impaired liver function due to their LiMAx scores, and furthermore, a small number of patients $(n=3)$ were below the previously chosen cutoff for open liver resections (31). With no cases of conversion and no mortality, 19\% developed minor complications (Clavien-Dindo I-II), while only one patient (4.8\%) developed a Clavien-Dindo IIla complications. No severe complication (Clavien-Dindo $\geq 1 \mathrm{llb}$ ) occured. Therefore, laparoscopic approaches became the standard for liver resections in cirrhosis at our center (32). Preoperative assessment of the hepatic function by serum levels of laboratory values (bilirubin, albumin, liver enzymes, international normalized ratio - INR) is always obligatory prior to hepatic resection, in our experience additional assessment of the complex hepatic metabolism, e.g. through LiMAx, is distinctly helpful in order to avoid postoperative liver function related complications, especially in patients with liver cirrhosis. In a meta-analysis, Witowski et al. stated significantly reduced overall morbidity of pure laparoscopic HCC resections in com- 
parison to open surgery, with no differences in mortality rate or survival (33). Sotiropoulos et al. found in another meta-analysis that the laparoscopic approach was associated with significantly lower blood loss and reduced need for blood transfusion, successful achievement of $\mathrm{R} 0$ resections as well as lower morbidity and lower 30-day mortality rates (34). Their results make the initiation of a prospective randomized trial on open versus laparoscopic liver resection for HCC in cirrhosis quite unlikely.

\section{Learning laparoscopic liver surgery}

While laparoscopic liver surgery was growing during the 1990s, experienced liver surgeons predominantly adapted their knowledge from open liver surgery procedures as well as from already well-established laparoscopic surgery programs in order to successfully promote the growth of the field. For the next generation of young liver surgeons, the International Laparoscopic Liver Society (ILLS) suggested to develop a structured surgical education program to increase the safety of patients, synergistic with the Iwate criteria as a tool to select a certain procedure based on the skill level (18). Based on data from all laparoscopic liver surgery procedures, which were performed at our center in 2017 and 2018, we suggested substeps for a curriculum for a two-year fellowship, which were submitted to the ILLS council and was further validated in a survey by 61 experienced liver surgeons from across the world (35). Complex surgical procedures were divided into 22 substeps, which can be separately executed by the laparoscopic liver surgeon fellow under observation of experienced laparoscopic liver surgeons, according to the fellow's level of training. Objective of the survey was to determine the difficulty of the various steps and how often certain substeps had to be executed by the fellow to perform the substeps without further observation. We concluded that basic skills (positioning of the patient, trocar placement, definition of resection margins based on ultrasound, etc.) as well as most fundamental skills (Pringle maneuver, parenchymal dissection with Iwate difficulty low and intermediate, etc.) can be successfully taught in centers with more 150 cases in two years. Advanced skills (dissection of the hepatic artery, portal vein and hepatic vein, dissection of the bile duct and hilar plate, etc.) can also be taught within 150 cases in two years, while a few advanced skills (hilar lymphadenectomy, parenchymal dissection with Iwate difficulty expert) are too rare to successfully be taught within two years. In addition, certain fundamental and advanced skills are too rare in centers with less than 100 laparoscopic liver resections in two years to comprehensively teach them to fellows. Therefore, a comprehensive training of laparoscopic liver surgeons is most suitable in highly specialized centers with more than 200 cases in two years.

\section{Limitations of laparoscopic liver surgery}

There are numerous limitations to the laparoscopic approach for liver resections. Previous abdominal surgeries - dependent on the type of procedure and the number of previous surgeries -often lead surgeons to favor open surgery because of abdominal adhesions, which frequently require time-consuming adhesiolysis.

Halls et al. could show previous open liver resection to be a risk factor for intraoperative complications in laparoscopic liver resections in a multi-center retrospective analysis, while previous laparoscopic and conventional open surgery in general and previous laparoscopic liver resections were not identified as risk factors (36). In an analysis of 319 laparoscopic liver resections between 2015 and 2018 at our center, 44\% of the patients had a history of previous abdominal surgery. We found postoperative complications with a Clavien-Dindo grade of $>3$ a to be similar in both groups (37). In our experience previous abdominal surgery should not be a general contra-indication for laparoscopic liver resection, but the choice of the procedure has to be well selected by an experienced laparoscopic liver surgeon. Another leading limitation is the reconstruction of the biliary tract. Performing a hepaticojejunostomy is a critical step even in open surgery and is reserved for liver surgeons with the highest experience. First reports of fully laparoscopic biliary reconstruction were made not long ago with a limited number of cases with respect to the rare indication (38-40). As expected, operating times were significantly longer than in the conventional open surgery groups, whereas rates of severe complications (Clavien-Dindo >III) were not different. With respect to these achievements, we do not expect further studies on laparoscopic biliary reconstruction in the near future nor the extensive implementation of this laparoscopic procedure in liver surgery programs across the world. The main reason is the growing interest and application of robotic minimally invasive surgery in our field.

\section{Pushing the Boundaries - Implementation of Robotic Liver Surgery}

\section{Robotic liver surgery}

The initial idea behind robotic surgery -which was created in the late 1960s- was to separate surgical expertise and the patient, in order to perform the highest standard of medical care far away from hospitals, e.g. for traumatic injury suffered in military foreign assignments, rather than bringing differently specialized surgeons into battlefield scenarios. This was one of the reasons the development of a robotic surgical device was financially supported by the US department of defense as one of the most important governmental institutions in the United States (41).

For this purpose, the technical foundation has to be on the highest possible level, incorporating attributions like three-dimensional visualization, a range of motion that is comparable to the surgeon's motions in conventional open surgery and a 
haptic feedback to feel tissue during surgery. The currently most common robotic device is the daVinci ${ }^{\circledR}$ system (Intuitive Surgical, Inc., Sunnycale, CA, USA) or its variations. The first daVinci ${ }^{\circledR}$ system was available in Europe in 1999. With the technical attributions of the system, which were originally designated for a different dedication, laparoscopic surgeons quickly discovered the potential of robotic surgery, furthermore because a potential gain in the surgeon's ergonomics, reduced fatigue over the time of a surgical procedures as well as a stable camera position. The first experience with robotic surgery in a liver-associated procedure was performed in 2001 in Italy with a preclinical study on minimally invasive cholecystectomy, back then with the ZEUS robotic system (Computer Motion Inc, Goleta, CA, USA) (42). First clinical reports on robotic liver surgery were published in the late 2000s about left lateral sectionectomies, unsurprisingly the same choice of segment combinations as in the first reports on laparoscopic liver resections in the mid 1990s $(19,20,23)$.

We started a robotic liver surgery program in 2018 in association with a single-center, prospective, post-marketing observational study (DRKS00017229) using the daVinci ${ }^{\circledR}$ Xi (Intuitive Surgical, Sunnycale, CA, USA). The development of the utilization of robotic liver surgery is displayed in Figure 1. In summary, the numbers of robotic liver surgery increased to a 5 -fold case load in two years. While minor resections were still performed laparoscopically to a large extent, major resections were dominantly allocated to the robotic approach. Last year we performed more robotic than laparoscopic resections for the first time, with an even share of major and minor robotic resections.

In a meta-analysis of 26 retrospective studies with 2630 patients undergoing robotic versus laparoscopic liver resection, there was no difference in intraoperative blood transfusion, conversion and Ro resection rates, as well as no difference in postoperative complications, hospital length of stay and 30-day and 90-day mortality (43). In a recently published retrospective, single-center study comparing difficulty of robotic $(n=91)$ versus laparoscopic $(n=92)$ liver resections, Chong et al. could show equal conversion and complication rates, equal hospital length of stay and rates of free resections margins in the general comparison. While operative times were prolonged in the robotic group, significantly more major resections were performed in the robotic group with a significantly higher difficulty rated by the Difficulty scoring system (44). It has therefore been shown, that for more difficult resections the surgeons' preference might tend towards the robotic approach, emphasizing the status of robotic surgery within MILS.

At our center, we found 59\% out of 126 patients undergoing robotic surgery within the first three years to have previous abdominal surgery in their patient history. Duration of surgery, conversion rates and postoperative complications were not significantly different between patients with and without previous abdominal surgery, with the exception of prior liver resections, which led to longer durations of surgery in only the univariate analysis (45). In our opinion, previous abdominal surgeries are no limitation nor contra-indication of robotic liver resection.

Postulated advantages of robotic liver resections overlap with certain advantages of laparoscopic liver surgery, e.g. less postoperative complications and pain, shorter hospital stays and consecutively a higher quality of life after surgery, because of minimally invasive approaches in both procedures. The quality of oncologic outcomes has been questioned and tested repeatedly during the development of MILS. A central point especially in the resection of iCC is the hilar lymphadenectomy (LAD). While hilar LAD used to be considered a contra-indication for MILS in the past, it has been shown to be safe and technically possible in the laparoscopic approach, consistence with the experience of our center $(14,46)$. Nevertheless, due to the 10-fold magnification of the daVinci ${ }^{\circledR}$ system robotic hilar LAD seems to be not only feasible but might also be superior to the laparoscopic hilar LAD (47). The miniaturization of the movements by the surgeon and the reduction of a natural tremor are other major advantages, especially when it comes to suturing. Therefore, the robotic approach seems to be suitable to perform biliary reconstruction in an easier way than in the laparoscopic procedure, which has been shown for resection of the pancreatic head with hepaticojejunostomy before (48). It also could pave the way for hepatic vessel reconstructions, e.g. in cases with portal vein resection.

A major disadvantage in the field of robotic surgery is the lack of established devices for the parenchymal dissection. While for laparoscopic resections all devices from open liver resections were adapted over time, for robotic liver resections extensively used ultrasound dissector are not available due to physical reasons, besides non-angulated devices like the Harmonic Ace Curved Shears (Ethicon, Somverille, NJ, USA), which we use for superficial parenchymal dissection (49). Beyond that, longer transition times of instruments are critical in case of especially severe intraoperative bleeding. We therefore extend the robotic procedure with a laparoscopic trocar for application of clips or staples during the parenchymal dissection, accepting higher expenditure per surgery for safety reasons.

\section{CONCLUSION}

Minimally invasive liver surgery grew rapidly over nearly three decades, with a major impact on standardization and safety through international meetings and foundation of an international society. Minimally invasive approaches has become the standard of care for patients undergoing liver resection across the world, including our own center at the Charité. Advantages over open surgery was shown independent of indications, tumor location and extent of the resection with a positive impact on intraoperative blood loss, postoperative pain, hospital length of stay and quality of life. Robotic liver surgery was 
adopted not long ago and will be the most discussed topic in MILS over the next years.

Peer-review: Externally peer-reviewed

Author Contributions: Concept - P.J.; Design - P.J., N.M., F.L.; Supervision - P.J.; Literature Review - N.M., P.J., F.L.; Writing Manuscript - N.M.; Critical Reviews - P.J., F.L.

Conflict of Interest: The authors declare that they have no conflict of interest.

Financial Disclosure: The authors declared that this study has received no financial support.

\section{REFERENCES}

1. Foures A, Ricordeau PJC. Sur la laparoscopie en pathologie hépatique [Laparoscopy in liver pathology]. Arch Mal Appar Dig Mal Nutr 1951; 40(12): 1342-3. [CrossRef]

2. Kaneko H, Takagi S, Shiba T. Laparoscopic partial hepatectomy and left lateral segmentectomy: Technique and results of a clinical series. Surgery 1996; 120(3): 468-75. [CrossRef]

3. Knitter S, Andreou A, Kradolfer D, Beierle AS, Pesthy S, Eichelberg A-C, et al. Minimal-invasive versus open hepatectomy for colorectal liver metastases: bicentric analysis of postoperative outcomes and long-term survival using propensity score matching analysis. J Clin Med 2020; 9(12): 4027. [CrossRef]

4. Andreou A, Struecker B, Raschzok N, Krenzien F, Haber P, Wabitsch S, et al. Minimal-invasive versus open hepatectomy for hepatocellular carcinoma: Comparison of postoperative outcomes and long-term survivals using propensity score matching analysis. Surg Oncol 2018; 27(4): 751-8. [CrossRef]

5. Fretland A, Vegar Ã, Dagenborg J, Maria G, Bjørnelv W, Kazaryan AM, et al. Laparoscopic versus open resection for colorectal liver metastases the OSLO-COMET. Randomized controlled trial. Ann Surg 2018; 267(2): 199-207. [CrossRef]

6. van Dam RM, van Breukelen GJP, Tanis PJ, Ratti F. Randomized clinical trial of open versus laparoscopic left lateral hepatic sectionectomy within an enhanced recovery after surgery programme ( ORANGE II study). Br J Surg 2017; 104(5): 525-35. [CrossRef]

7. Katkhouda N, Hurwitz M, Gugenheim J, Mavor E, Mason RJ, Waldrep $D J$, et al. Laparoscopic management of benign solid and cystic lesions of the liver. Ann Surg 1999; 229(4): 460-6. [CrossRef]

8. Descottes B, Glineur D, Lachachi F, Valleix D, Paineau J, Hamy A, et al. Laparoscopic liver resection of benign liver tumors: Results of a multicenter European experience. Surg Endosc 2003; 17(1):23-30. [CrossRef]

9. Nguyen KT, Gamblin TC, Geller DA. World review of laparoscopic liver resection-2,804 patients. Ann Surg 2009; 50(5): 831-41. [CrossRef]

10. Schmelzle M, Wabitsch S, Haber PK, Krenzien F, Kästner A, Biebl M, et al. Laparoscopic liver surgery - a single centre series of 250 consecutive cases. Zentralb/ Chir 2019; 144(2): 145-52. [CrossRef]

11. Zhang X, Liu R, Zhang D, Zhang Y, Wang T. Laparoscopic versus open liver resection for colorectal liver metastases: A systematic review and meta-analysis of studies with propensity score-based analysis. Int J Surg 2017; 44: 191-203. [CrossRef]

12. Xie S, Xiong J, Liu X, Chen H, Iglesia-garcía D, Bharucha S, et al. Laparoscopic versus open liver resection for colorectal liver metastases: a comprehensive systematic review and meta-analysis. Sci Rep 2017; 7(1): 1012. [CrossRef]
13. Cho JY, Han H. Laparoscopic liver resection for hepatocellular carcinoma in patients with cirrhosis. Hepatoma Res 2016;2:259-63. [CrossRef]

14. Haber PK, Wabitsch S, Kästner A, Andreou A, Krenzien F, Schöning W, et al. Laparoscopic liver resection for intrahepatic cholangiocarcinoma: a single-center experience. J Laparoendosc Adv Surg Tech 2020; 30(12): 1354-9. [CrossRef]

15. Buell JF, Cherqui D, Geller DA, O'Rourke N, lannitti D, Dagher I, et al. World Consensus Conference on Laparoscopic Surgery. The international position on laparoscopic liver surgery: The Louisville Statement, 2008. Ann Surg 2009; 250(5): 825-30. [CrossRef]

16. Wakabayashi G, Cherqui D, Geller DA, Buell JF, Kaneko H, Han HS, et al. Recommendations for laparoscopic liver resection: a report from the second international consensus conference held in morioka. Ann Surg 2015; 261(4):619-29. [CrossRef]

17. Ban D, Tanabe M, Ito H, Otsuka Y, Nitta H, Abe Y, et al. A novel difficulty scoring system for laparoscopic liver resection. J Hepatobiliary Pancreat Sci 2014; 21(10): 745-53. [CrossRef]

18. Wakabayashi G. What has changed after the Morioka consensus conference 2014 on laparoscopic liver resection? Hepatobiliary Surg Nutr 2016; 5(4): 281-919. [CrossRef]

19. Choi SB, Park JS, Kim JK, Hyung WJ, Kim KS, Yoon DS, et asl. Early experiences of robotic-assisted laparoscopic liver resection. Yonsei Med J 2008; 49(4): 632-8. [CrossRef]

20. Vasile S, Sgarburã O, Tomulescu V, Popescu I. The robotic-assisted left lateral hepatic segmentectomy: the next step. Chir 2008; 103(4): 401-5. [CrossRef]

21. Cipriani F, Shelat VG, Rawashdeh M, Francone E, Aldrighetti L, Takhar A, et al. Laparoscopic parenchymal-sparing resections for nonperipheral liver lesions, the diamond technique: technical aspects, clinical outcomes, and oncologic efficiency. J Am Coll Surg 2015; 221 (2): 26572. [CrossRef]

22. Haber PK, Wabitsch S, Krenzien F, Benzing C, Andreou A, Schöning $W$, et al. Laparoscopic liver surgery in cirrhosis - Addressing lesions in posterosuperior segments. Surg Oncol 2019; 28: 140-4. [CrossRef]

23. Azagra JS, Goergen M, Gilbart E, Jacobs D. Laparoscopic anatomical (hepatic) left lateral segmentectomy - Technical aspects. Surg Endosc 1996; 10(7): 758-61. [CrossRef]

24. Wabitsch S, Kästner A, Haber PK, Feldbrügge L, Winklmann T, Werner $S$, et al. Laparoscopic versus open hemihepatectomy - a cost analysis after propensity score matching. Langenbeck's Arch Surg 2019; 404(4): 469-75. [CrossRef]

25. Yoon $\mathrm{Yl}$, Kim KH, Kang SH, Kim WJ, Shin MH, Lee SK, et al. Pure laparoscopic versus open right hepatectomy for hepatocellular carcinoma in patients with cirrhosis. Ann Surg 2017; 265(5): 856-63. [CrossRef]

26. Shelat VG, Cipriani F, Basseres T, Armstrong TH, Takhar AS, Pearce NW, et al. Pure laparoscopic liver resection for large malignant tumors: does size matter? Ann Surg Oncol 2015; 22(4): 1288-93. [CrossRef]

27. Wabitsch S, Schöning W, Kästner A, Haber PK, Benzing C, Krenzien F, et al. A propensity-matched study of full laparoscopic versus hand-assisted minimal-invasive liver surgery. Surg Endosc 2021; 35(5): 2021-8. [CrossRef]

28. Llovet JM, Kelley RK, Villanueva A, Singal AG, Pikarsky E, Roayaie S, et al. Hepatocellular carcinoma. Nat Rev Dis Prim 2021; 7(1): 6. [CrossRef]

29. Seehofer D, Sucher R, Schmelzle M, Öllinger R, Lederer A, Denecke T, et al. Evolution of laparoscopic liver surgery as standard procedure for HCC in cirrhosis? Z Gastroenterol 2017; 55(5):453-60. [CrossRef] 
30. Stockmann M, LockJF, Riecke B, Heyne K, Martus P, Fricke M, et al. Prediction of postoperative outcome after hepatectomy with a new bedside test for maximal liver function capacity. Ann Surg 2009; 250(1): 119-25. [CrossRef]

31. Stockmann M, Lock JF, Malinowski M, Niehues SM, Seehofer D, Neuhaus P. The LiMAx test: A new liver function test for predicting postoperative outcome in liver surgery. HPB 2010; 12(2): 139-46. [CrossRef]

32. Schmelzle M, Krenzien F, Schöning W, PratschkeJ. Treatment of hepatocellular carcinoma in the cirrhotic and non-cirrhotic liver. Chirurg 2018; 89(11): 851-7. [CrossRef]

33. Witowski J, Rubinkiewicz M, Mizera M, Wysocki M, Gajewska N. Meta-analysis of short- and long-term outcomes after pure laparoscopic versus open liver surgery in hepatocellular carcinoma patients. Surg Endosc 2019; 33(5): 1491-507. [CrossRef]

34. Sotiropoulos GC, Prodromidou A, Kostakis ID, Machairas N. Meta-analysis of laparoscopic vs open liver resection for hepatocellular carcinoma. Updates Surg 2017; 69(3): 291-311. [CrossRef]

35. Krenzien F, Schöning W, Brunnbauer P, Benzing C, Öllinger R, Biebl M, et al. The ILLS laparoscopic liver surgery fellow skills curriculum. Ann Surg 2020; 272(5): 786-92. [CrossRef]

36. Halls MC, Berardi G, Cipriani F, Barkhatov L, Lainas P, Harris S, et al. Development and validation of a difficulty score to predict intraoperative complications during laparoscopic liver resection. Br J Surg 2018; 105(9): 1182-91. [CrossRef]

37. Feldbrügge L, Wabitsch S, Benzing C, Krenzien F, Kästner A, Haber PK, et al. Safety and feasibility of laparoscopic liver resection in patients with a history of abdominal surgeries. HPB 2020; 22(8): 1191-6. [CrossRef]

38. Feng F, Cao X, LiuX, Qin J, Zhang S, Li Q, et al. Laparoscopic resection for Bismuth type III and IV hilar cholangiocarcinoma: How to improve the radicality without direct palpation. J Surg Oncol 2019; 120(8): 1379-85. [CrossRef]

39. Ratti F, Fiorentini G, Cipriani F, Catena M, Paganelli M, Aldrighetti L. Perihilar cholangiocarcinoma: are we ready to step towards minimally invasiveness? Updates Surg 2020; 72(2): 423-33. [CrossRef]
40. Zhang Y, Dou C, Wu W, Liu J, Jin L, Hu Z, et al. Total laparoscopic versus open radical resection for hilar cholangiocarcinoma. Surg Endosc 2020; 34(10): 4382-7. [CrossRef]

41. George El, Brand TC, LaPorta A, Marescaux J, Satava RM. Origins of robotic surgery: from skepticism to standard of care. JSLS J Soc Laparoendosc Surg 2018; 22(4):e2018.00039. [CrossRef]

42. Lomanto D, Cheah WK, So JB, Goh PM. Robotically assisted laparoscopic cholecystectomy: A pilot study. Arch Surg 2001; 136(10): 1106-8. [CrossRef]

43. Kamarajah SK, Bundred J, Manas D, Jiao LR, Hilal MA, White SA. Robotic versus conventional laparoscopic liver resections: a systematic review and meta-analysis. Scand J Surg 2020:1-11. [CrossRef]

44. Chong CCN, Lok HT, Fung AKY, Fong AKW, Cheung YS, Wong J,et al. Robotic versus laparoscopic hepatectomy: application of the difficulty scoring system. Surg Endosc 2020; 34(5): 2000-2006. [CrossRef]

45. Feldbrügge L, Ortiz Galindo SA, Frisch O, Benzing C, Krenzien F, Riddermann $A$, et al. Safety and feasibility of robotic liver resection after previous abdominal surgeries. Surg Endosc 2021. [CrossRef]

46. Ratti F, Cipriani F, Ariotti R, Gagliano A, Paganelli M, Catena M, et al. Safety and feasibility of laparoscopic liver resection with associated lymphadenectomy for intrahepatic cholangiocarcinoma: a propensity score-based case-matched analysis from a single institution. Surg Endosc 2016; 30(5): 1999-2010. [CrossRef]

47. Machado MA, Mattos BV, Lobo Filho MM, Makdissi F. Robotic resection of hilar cholangiocarcinoma. Ann Surg Oncol 2020; 27(11): 4166-70. [CrossRef]

48. Müller-Debus CF, Thomaschewski M, Zimmermann M, Wellner UF, Keck T. Robot-assisted pancreatic surgery. Zentralb/ Chir 2020; 145(3): 260-70. [CrossRef]

49. Schmelzle M, Schöning W, Pratschke J. Liver surgery - setup, port placement, structured surgical steps: standard operating procedures in robot-assisted liver surgery. Zentralblatt fur Chir 2020; 145(3): 246-51. [CrossRef]

\section{DERLEME-ÖZET}

Turk J Surg 2021; 37 (3): 199-206

\section{Karaciğerin minimal invaziv cerrahisi: Charité deneyimi}

Maximilian Nösser, Linda Feldbrügge, Johann Pratschke

Cerrahi Kliniği, Universitätsmedizin Berlin, Campus Charité Mitte ve Campus Virchow-Klinikum, Berlin, Almanya

\section{ÖZET}

Minimal invazif karaciğer cerrahisi (MiKC), 1990'lı yıllarda karın cerrahisi uzmanlığının gelişen en son parçasıdır. Önceleri ağırlıklı olarak benign endikasyonlardan malign endikasyonlara olan değişim ile MiKC'nin, intraoperatif kan kaybı, postoperatif ağrı, postoperatif komplikasyon oranı, hastanede kalış süresi ve hayat kalitesi bakımından sağladığı yararlar ile onkolojik sonuçlar açısından açık karaciğer cerrahisine eşdeğer olduğu gösterilmiştir. Kolorektal karaciğer metastazları ve hepatosellüler karsinom endikasyonlarda başı çekerken, günümüzde karaciğer sirozu olan hastalarda dahi birçok karaciğer rezeksiyonu minimal invazif yöntemlerle yapılmaktadır. Laparoskopik karaciğer cerrahisi ile ilgili erken dönemde düşünülen sınırlılıklar, kazanılan deneyimler, teknik alanda ilerlemeler ve yeni rezeksiyon yaklaşımları sonucunda etkisini kaybetmeye başlamıştır. Son yıllarda, sınırları iyice zorlamak adına robotik karaciğer cerrahisi de MIKC alanına uygulanmıştır. İlk rezeksiyonları basitleştirmek için minimal invazif yaklaşımın teknik varyasyonları kullanılabilmekte ve tecrübe seviyesine uygun rezeksiyonların seçiminde zorluk skorları da yardımcı olmaktadır. Bu çalışmanın amacı, merkezimizde başlattığımız minimal invazif karaciğer cerrahisi programının bir özetini sunmaktır.

Anahtar Kelimeler: Minimal invaziv karaciğer cerrahisi, laparoskopik karaciğer cerrahisi, robotik karaciğer cerrahisi, laparoskopi, karaciğer, robotik

Doi: $10.47717 /$ turkjsurg.2021.1011 